\title{
Mandenkan
}

MANDENIKAN Bulletin semestriel d'études linguistiques mandé

$57 \mid 2017$

Numéro 57

\section{Field Notes on Kono, a Southwestern Mande Lect of Forest Guinea}

Notes de terrain sur le kono, une vari

été du groupe mandé sud-ouest,

Guinée Forestière

ПОЛЕВЫЕ ЗАМЕТКИ О КОНО, ИДИОМЕ ЮГО-ЗАПАДНОЙ ГРУППЫ МАНДЕ, ЛЕСНАЯ

ГВИНЕЯ

\section{Maria Konoshenko}

\section{CpenEdition}

\section{Journals}

Electronic version

URL: https://journals.openedition.org/mandenkan/1092

DOI: 10.4000/mandenkan.1092

ISSN: $2104-371 X$

Publisher

Llacan UMR 8135 CNRS/Inalco

\section{ELECTRONIC REFERENCE}

Maria Konoshenko, "Field Notes on Kono, a Southwestern Mande Lect of Forest Guinea", Mandenkan [Online], 57 | 2017, Online since 14 December 2017, connection on 08 July 2021. URL: http://journals.openedition.org/mandenkan/1092 ; DOI: https:// doi.org/10.4000/mandenkan.1092

This text was automatically generated on 8 July 2021.

Les contenus de Mandenkan sont mis à disposition selon les termes de la Licence Creative Commons Attribution - Pas d'Utilisation Commerciale - Partage dans les Mêmes Conditions 4.0 International. 


\section{Field Notes on Kono, a Southwestern Mande Lect of Forest Guinea $^{1}$}

Notes de terrain sur le kono, une vari

été du groupe mandé sud-ouest,

Guinée Forestière

ПОЛЕВЫЕ ЗАМЕТКИ О КОНО, ИДИОМЕ ЮГО-ЗАПАДНОЙ ГРУППЫ МАНДЕ, ЛЕСНАЯ

ГВИНЕЯ

Maria Konoshenko

\section{Introduction}

1 The Kono (knu) lect described here belongs to Southwestern Mande group. It is one of minority lects of the Republic of Guinea, not to be confused with Kono of Sierra Leone (kno, Kono-Vai group). Kono is spoken by ca. 90000 people in Lola Prefecture located in the eastern part of Forest Guinea, bordering the Ivory Coast and Liberia.

2 Kono is a member of the Kpelle macro-language also comprising Guinean Kpelle (gkp) and Liberian Kpelle (xpe). Since their taxonomic status is somewhat controversial, I use the terms "lect"/"variety" to refer to these three language forms. However, as I demonstrate in this sketch, Kono is lexically and grammatically distinct enough to be considered a separate language. To date, no descriptions of Kono are available.

3 Though it is undoubtedly a Southwestern Mande lect, Kono has some phonological and syntactic properties shared with neighbouring Southern Mande languages, e.g., first vowel elision in CVLV structures and obligatory pronominal doubling of definite noun phrases.

4 The data presented here were collected at several sessions with two speakers of Kono, Sèni Doré (born in 1965) and Bala Bamba (born in 1956) during my field trips to the 
Republic of Guinea in 2009 and 2014, where I primarily worked on Guinean Kpelle as my primary area of research. I am also very grateful to Souanan Doré and Jean Gbemou, both native speakers of Kono, as well as two anonymous reviewers for their useful comments and corrections.

5 Guinean Kpelle data mentioned in this paper are based on my own field materials; they pertain to the hỡ Forest Guinea, which I assume to be the "basic" Guinean Kpelle dialect. All information concerning Liberian Kpelle is taken from Welmers (1962), Leidenfrost and McKey (2005). Other sources on Guinean and Liberian Kpelle are mentioned in the references.

The following are some general typological properties of Kono:

- There are seven oral vowels and five nasal vowels.

- There are labiovelar /kp/, /gb/, /ym/, labialized /kw/, /gw/, /hw/, /yw/ and implosive /6/ consonants, among others.

- Initial consonants make up a system of morphophonemic alternations with binary contrast for sonorants and three-way contrast for obstruents.

- There is a binary $\mathrm{H}$ vs. $\mathrm{L}$ tone system with contextual mid tone, $\mathrm{H}$ tone spread, tone polarity, downstep and downdrift.

- Basic word order is S Aux O V X.

- There are three types of possessive constructions distinguishing between kinship terms, body parts names and free nouns.

- There is inclusive vs. exclusive distinction in person markers.

- TAM markers in the auxiliary slot inflect for person and number and generally co-occur with lexical subjects.

\section{Segmental phonology}

Table 1. Vowels

\begin{tabular}{|c|c|c|c|c|c|c|}
\hline \multicolumn{3}{|l|}{ Oral } & & \multicolumn{3}{|l|}{ Nasal } \\
\hline Front & Central & Back rounded & & Front & Central & Back rounded \\
\hline$i$ & & $u$ & $\eta$ & $\underset{i}{i}$ & & $\underset{\sim}{u}$ \\
\hline$e$ & & 0 & & & & \\
\hline$\varepsilon$ & & 0 & & $\varepsilon$ & & $\stackrel{2}{\sim}$ \\
\hline & $a$ & & & & $\underset{\sim}{a}$ & \\
\hline
\end{tabular}

COMMENT: WORD finAL/y/ IS TREATEd AS A VOWEL BECAUSE IT CARRIES TONE.

Table 2. Consonants

\begin{tabular}{|l|l|l|l|l|l|l|l|}
\hline & Labial & Coronal & Palatal & Velar & Labiovelar & Labialized & Glottal \\
\hline Voiceless stops & $p$ & $t$ & & $k$ & $k p$ & $k w$ & \\
\hline
\end{tabular}




\begin{tabular}{|l|l|l|l|l|l|l|l|}
\hline Voiced stops & $b$ & $d$ & & $g$ & $g b$ & $g w$ & \\
\hline Implosives & $b$ & & & & & & \\
\hline Voiceless fricatives & & & & & & $h w$ & $h$ \\
\hline Voiced fricatives & $v$ & & & $\gamma$ & & & \\
\hline Voiced affricates & & $d z / z$ & & & & & \\
\hline Oral sonorants & & $r, l$ & $y$ & & $w$ & & \\
\hline Nasal sonorants & $m$ & $n$ & $n$ & $y$ & $y m$ & $y w$ & \\
\hline
\end{tabular}

Comments: 1) [dz] and [z] are variants of the same phoneme.

2) $/ \mathrm{nm} /$, /nv/ and initial / $\mathrm{g} /$ segments only appear as a result of initial consonant alternation (2.4), they do not occur in lexical representations.

\subsection{Alveolar flap / / /}

7 Kono has alveolar flap / $\mathrm{f} /$ occurring intervocally, represented here as $r$ for typographic simplicity. Intervocalic / $/$ / and /l/ are contrastive after word-initial labials, velars, labiovelars and labialized consonants, but only / $\mathrm{f} /$ occurs after word-initial coronal and palatal consonants. This restriction suggests that there are elements of consonant harmony, or "homoresonance" in Kono, which is also attested in Southern Mande languages (Le Saout 1979; Bearth 1992), but not in other Kpelle lects. In Liberian Kpelle, etymological contrast between $/ \varsigma /$ and $/ 1 /$ is preserved after all initial consonants, and in Guinean Kpelle these two phonemes merged into /1/. Consider the series of cognates in Table 3; cf. also Table 4 below.

Table 3. Intervocalic / $/$ and /l/.

\begin{tabular}{|c|c|c|c|}
\hline Kono & Liberian Kpelle & Guinean Kpelle & Meaning \\
\hline péré & péré & pélé & 'house' \\
\hline kéréń & kéréý & kéléń & 'burn' \\
\hline kćlêे & kélغ̀ & kélê & 'beat' \\
\hline kplá & kpálá & kpálá & 'be dry' \\
\hline yírê & yílà & yílê & 'dog' \\
\hline léré & lćlé & lélé & 'good' \\
\hline
\end{tabular}




\subsection{Vowel elision in stems with intervocalic ///}

In stems with intervocalic /1/ such as CVlV, CVlVy, CVlVV etc., the first vowel is often dropped in Kono. ClV and similar structures are not attested in other Kpelle varieties but they are typical for neighbouring Southern Mande languages, e.g., Dan-Gwectaa (Vydrine \& Kességbeu 2008) and Kla-Dan (Makeeva 2012). Consider the series of cognates in Table 4.

Table 4. Vowel elision in CVIV and similar structures.

\begin{tabular}{|c|c|c|c|}
\hline Kono & Liberian Kpelle & Guinean Kpelle & Meaning \\
\hline klóń & kólóń & kólóń & 'know’ \\
\hline kplè & kpēlè & kpèlè & ‘drink’ \\
\hline bláá & Gálá & béláá & 'sheep' \\
\hline
\end{tabular}

\subsection{Vowel shortening}

$9 \mathrm{CV}_{1} \mathrm{~V}_{1}$ stems with identical vowels, as well as stem initial $\mathrm{CV}_{1} \mathrm{~V}_{1}$ - structures in non-monosyllabic stems are shortened in Kono; cf. Table 5.

Table 5. $\mathrm{CV}_{1} \mathrm{~V}_{1}$ shortening.

\begin{tabular}{|l|l|l|l|}
\hline Kono & Liberian Kpelle & Guinean Kpelle & Meaning \\
\hline$k a ́$ & káá & káá & 'see' \\
\hline hě & sēe & hèe & 'sit' \\
\hline hwèrě & feèr $\bar{\varepsilon}$ & hvèelě & 'two' \\
\hline
\end{tabular}

\subsection{Initial consonant alternation}

As in other Kpelle lects, initial consonants make up a system of alternations in Kono.

\begin{tabular}{|l|l|l|l|l|l|l|l|}
\hline$(1)$ & $\mathrm{p} \rightarrow \mathrm{m} / \mathrm{b}$ & $\mathrm{t} \rightarrow \mathrm{n} / \mathrm{d}$ & $\mathrm{k} \rightarrow \mathrm{y} / \mathrm{g}$ & $\mathrm{kw} \rightarrow \mathrm{yw} / \mathrm{gw}$ & $\mathrm{kp} \rightarrow \mathrm{ym} / \mathrm{gb}$ & $\mathrm{hw} \rightarrow \mathrm{nv} / \mathrm{v}$ & $\mathrm{h} \rightarrow \mathrm{n} / \mathrm{dz}$ \\
\hline & $\mathrm{b} \rightarrow \mathrm{m}$ & $\mathrm{l} \rightarrow \mathrm{n}$ & $\mathrm{y} \rightarrow \mathrm{n}$ & $\mathrm{w} \rightarrow \mathrm{yw}$ & & & \\
\hline
\end{tabular}

11 The alternation appears as a result of the voicing and nasalization of non-nasal consonants (given to the left) in *NC sequences. Lexical obstruents, e.g., /p/, alternate with nasal and non-nasal voiced alternants, e.g., /m/ and /b/. Non-obstruents, e.g., implosive /6/, alternate with nasals, e.g., /m/. 

melody. It is marked with haček on final vowel in the orthography: pă 'to kill', hùyŏ

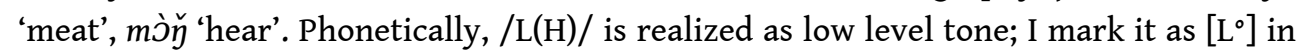
the surface transcription. For the sake of clarity, the conventions for $/ \mathrm{L}(\mathrm{H}) /$ are represented in (3):

\begin{tabular}{|l|l|l|l|l|l|l|l|l|}
\hline (3) & Underlying: & /pa/ & Orthographic: & pă & Surface: & [pà] & (level L) \\
\hline & & 1 & & & & & \\
\hline
\end{tabular}




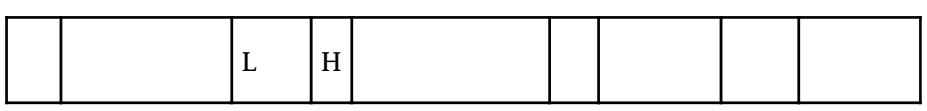

(L) is a floating low tone that is specific for person markers encoding alienable possession - see 3.2 and 4.1. It is marked with a 'sign after the stem.

The /HL/ pattern is realized as [H-HL] on CVCV stems and as [H-L] on CVV stems.

The following tonal rules exist in Kono: downdrift (3.1), downstep (3.2), contour simplification (3.3), tonal polarity (3.4) and H spread (3.5). I discuss the propagation of prefixal high and low tones in 3.6.

\subsection{Downdrift}

Downdrift is a general phonetic phenomenon whereby every next high tone is pronounced lower after a low tone and every next low tone is pronounced lower after a

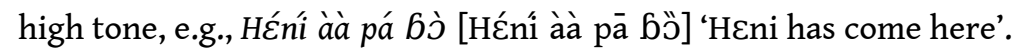

\subsection{Downstep}

Downstep occurs when high tone is pronounced lower after a low tone, which in turn, is deleted. This occurs at least in three types of phonetic environments in Kono.

First, downstep takes place after a falling contour on word final syllable [-HL] in /HL/ and /LHL/ melodies; final L of the contour is then deleted; cf. contour simplification in 3.3. This is shown in (4).

(4) $-\mathrm{HL}+/ \mathrm{H} / \rightarrow[-\mathrm{H}]+$ ![H]: /yírê ká/ $\rightarrow$ [yíré !ká] 'to see a dog'

This type of downstep is also attested in Guinean Kpelle (cf. Konoshenko 2014).

The second type of downstep is unique to Kono; it is attested on $\mathrm{ClV}(\mathrm{y})$ stems with an elided vowel (see 2.2) and bearing lexical / $\mathrm{H} /$ melody. In such stems, $\mathrm{H}$ tone is downstepped in alternated prefixal 3sG forms described in 2.4, e.g., for lexical klóń 'know' in (5-6):

(5) [yá Héní klóń] 'I know Hعni’.

(6) [yá !glóń] 'I know him/her'.

There is no downstep in (5), where the verb appears in its lexical form. In (6), H tone of the verb with $3 \mathrm{SG}$ object prefix is downstepped. I assume that this form is underlyingly /*gòlóń/, which is how it is actually realized in Guinean Kpelle. The downstep occurs after the first vowel is elided 5 .

Finally, downstep occurs after alienable possessive markers. Except for the 3sG marker with only linked L given in (7), they all bear linked $\mathrm{H}$ and presumably, floating (L) triggering downstep on the following noun with /H/, as in (8); cf. also 5.1.
(7) /yò bláá/ $\rightarrow$ [yò Gláá] 'his sheep'
(8) /ý bláá/ $\rightarrow$ [ý !bláá] 'my sheep' 


\subsection{Contour simplification}

Contour simplification is a process whereby any word final (i.e., linked to word final syllable) falling sequence $\mathrm{HL}$ becomes $[\mathrm{H}]$ before another tone.

When word final -HL is followed by L, which may be /L/, /L(H)/ or /LHL/, its L is absorbed into the following $\mathrm{L}(9)$.

(9) $-\mathrm{HL}+$ /L/ $\rightarrow[\mathrm{H}]+$ [L]: /yírê kà/ $\rightarrow$ [yíré kà] 'saw a dog'

When followed by $\mathrm{H}-/ \mathrm{H} /$ or / $\mathrm{HL} /$, final $\mathrm{L}$ of the contour is deleted and the following $\mathrm{H}$ is downstepped (cf. 3.2). ${ }^{6}$ Since contours are always simplified before $\mathrm{H}$ or L, they only occur utterance finally or in isolation.

\subsection{Tonal polarity}

Tonal polarity is a property of resultative person markers (sections $4.3,6.7$ ). Their tone is always the opposite of the following tone, as shown in (10-11).

(10) [àà pá] 'he has come'

(11) [áá hè] 'he sat down'

The tone of adverb nii 'yet', used in negative resultative construction (6.8) and of the future marker $k \varepsilon \varepsilon$ (6.12) is the opposite of the preceding tone:

\begin{tabular}{|l|l|l|l|}
\hline$(12)$ & {$[$ hó } & nìi & pá-nî] \\
\hline & 2SG.B.NEG & yet & come-STAT \\
\hline
\end{tabular}

'You have not come yet'.

\begin{tabular}{|l|l|l|l|}
\hline$(13)$ & {$[$ hò } & nîii & pá-nî] $]$ \\
\hline & 3SG.B.NEG & yet & come-STAT \\
\hline
\end{tabular}

'(S)he has not come yet'.

Thus, both progressive and regressive polarity is attested in Kono.

\subsection{H spread}

Linked $\mathrm{H}$ tone of /H/ spreads on the following /L/ melody, which becomes [HL], as shown in (14). The domain of this rule is a syntactic constituent: verb phrase, noun phrase and postpositional phrase.

(14) /H/ + /L/ $\rightarrow[\mathrm{H}]+[\mathrm{HL}]:$ /6láá kà/ $\rightarrow$ [Gláá kâ] 'saw a sheep'7

However, there is no expected change after floating $(\mathrm{H})$ in $/ \mathrm{L}(\mathrm{H}) /$ :

$(15) / \mathrm{L}(\mathrm{H}) /+/ \mathrm{L} / \rightarrow[\mathrm{L}]+[\mathrm{L}]:$ /wòlǒ tò $/ \rightarrow$ [wòlò tò] 'sang a song' 

(17) above, the verb to 'fall' has lexical /L(H)/ melody. In (15) the verb is assigned a replacive /L/ tonal morpheme, completely overriding lexical tones in past construction (see section 6 on basic TAM constructions). Both lexical and - in specific constructions - grammatical melodies serve as input or underlying structure in the case of phonological operations discussed in this section. In the following, I mark underlying tones in language examples, except for forms with 1sG and 3sG prefixes and those few cases where I am unsure about underlying tones.

\section{Person markers}

There are several morphosyntactic types of person markers in Kono: strong pronouns (4.1), person indexes (4.2), predicative (4.3), possessive (4.4), locative (4.5) and conjunctive (4.6) person markers. The general property of all these types is the difference between exclusive and inclusive forms, which is also characteristic of Guinean Kpelle but is not attested in Liberian Kpelle. 


\subsection{Strong pronouns}

Strong (free, emphatic) pronouns are the only type of person markers in Kono that can be regarded as pronouns sensu stricto. They are used in focus constructions, with copulas and as second conjuncts in noun phrase coordination (5.6).

Table 6. Strong pronouns.

\begin{tabular}{|l|l|l|l|l|l|l|}
\hline 1 sg & $2 \mathrm{sg}$ & $3 \mathrm{sg}$ & $1 \mathrm{pl} \cdot \mathrm{excl}$ & $1 \mathrm{pl} . \mathrm{incl}$ & $2 \mathrm{pl}$ & $3 \mathrm{pl}$ \\
\hline ná & 6 íé & yà & nòwá & gòwá & káá & dòwá \\
\hline
\end{tabular}

\subsection{Person indexes}

Person indexes encode verb and postposition complements, inalienable possessors and single arguments in stative-resultative construction (cf. 6.17); 1sG and 3sG markers are realized as initial consonant alternation with high and low tone, respectively (cf. 2.4, 3.6). They do not co-occur with full noun phrases in the same syntactic position, except for possessive construction with kinship terms (5.1), or in cases when the noun phrase has a definite marker (5.4), or the noun phrase is encoded by person index with quantifier hénć 'all' (5.5), or when there are conjoint noun phrases (5.6).

Table 7. Person indexes.

\begin{tabular}{|l|l|l|l|l|l|l|}
\hline $1 \mathrm{sg}$ & $2 \mathrm{sg}$ & $3 \mathrm{sg}$ & $1 \mathrm{pl} \cdot \mathrm{excl}$ & $1 \mathrm{pl}$.incl & $2 \mathrm{pl}$ & $3 \mathrm{pl}$ \\
\hline$(\dot{\eta}-)$ & $\dot{e}-$ & $(\grave{\eta}-)$ & $n \check{u}-$ & $g \check{u}-$ & $k a ́-$ & $d \check{u}-$ \\
\hline
\end{tabular}

\subsection{Predicative person markers}

Predicative person markers, often called subject pronouns, are portmanteau forms encoding person-number and TAM meanings. Historically, they appeared as a result of fusion between person markers with auxiliaries or predicative markers. Crucially, most such markers co-occur with subject noun phrases in the same clause; they function as local agreement markers if there is an overt subject noun phrase (18) and as anaphoric markers without an overt subject (19). Therefore, I label them predicative person markers rather than subject pronouns.

\begin{tabular}{|l|l|l|l|}
\hline$(18)$ & G’̀pú & $a a$ & $p a ́$. \\
\hline & Gopu & 3sG.RES & come \\
\hline
\end{tabular}




\begin{tabular}{|l|l|l|}
\hline$(19)$ & Aa & pá. \\
\hline & 3SG.RES & come \\
\hline
\end{tabular}

'(s)he has come'.

In all TAM constructions where they appear, basic negative person markers do not cooccur with full lexical 3sG subjects containing no definiteness marker. In (20), a default negative marker is used that is underlyingly toneless; in (21), a basic negative person marker is used after a lexical subject with definiteness marker -kí. In (22), basic negative person marker is used anaphorically.

\begin{tabular}{|l|l|l|l|l|l|}
\hline (20) & Héni & ho & é-klóń. & & \\
\hline & Heni & NEG & 2SG-know & \\
\hline
\end{tabular}

'Heni doesn't know you'.

\begin{tabular}{|l|l|l|l|l|}
\hline (21) & Lóhòrò-kíi & hò & Héní & klóń. \\
\hline & child-DEF & 3SG.NEG & Heni & know \\
\hline
\end{tabular}

67 'The child doesn't know Heni'.

\begin{tabular}{|l|l|l|l|}
\hline (22) & Hò & é-klóń. & \\
\hline & 3SG.NEG & 2SG-know & \\
\hline
\end{tabular}

‘(S)he doesn't know you'.

69 The difference between the uninflected default marker and 3sG marker is that the tone of the former is spread from the subject (cf. 23-24), while the latter always surfaces with low tone. Thus, the default negative marker is inherently toneless in Kono (cf. hó in Guinean Kpelle, $f e$ in Liberian Kpelle).

\begin{tabular}{|l|l|l|l|l|}
\hline (23) & Pépèe & {$[$ hò] } & Héní & klóý. \\
\hline & Pepee & NEG & Heni & know \\
\hline
\end{tabular}

‘Pepee doesn’t know Hعni’. 


\begin{tabular}{|l|l|l|l|l|}
\hline (24) & Yàràmó & {$[$ hó] } & Héní & klóý. \\
\hline & Yaramo & NEG & Heni & know \\
\hline
\end{tabular}

\begin{tabular}{|l|l|l|l|}
\hline$(28)$ & Gá & nóó & ýíí-nî. \\
\hline & 3SG.EXI & sauce & cook-STAT \\
\hline
\end{tabular}

It should be noted that the paradigm of existential markers is made up of person markers and two different predicators, ká and nà. Interestingly, ká occurs with low tone 
person markers and nà with high tone person markers (cf. table 8). However, only the nà marker is used in negative progressive construction (6.10).

A full paradigm of predicative person markers in Kono is given in table 8.

Table 8. Predicative person markers.

\begin{tabular}{|c|c|c|c|c|c|c|c|c|}
\hline & Series & $1 \mathrm{SG}$ & $2 \mathrm{SG}$ & $3 \mathrm{SG}$ & 1PL.EXCL & 1PL.INCL & 2PL & 3PL \\
\hline \multirow[t]{6}{*}{ Affirmative } & I. Basic positive & páá & é & $\grave{e}$ & $n \check{~}$ & gǔ & ká & $d \check{~}$ \\
\hline & II. Resultative ${ }^{10}$ & nas & $6 a a$ & $a a$ & nwaa & gwas & kas & $d a a$ \\
\hline & III. Existential & tínà & énà & gá & nùká & gùká & kánà & dùká \\
\hline & IV. Future & 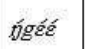 & $k \varepsilon^{\prime} \varepsilon$ & พฉ̀े & nùké & gùké & káká & dùké \\
\hline & V. Imperative & - & $\varnothing$ & $6 \grave{0}$ & - & 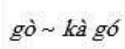 & $k \grave{a}$ & $d u ̀ ~$ \\
\hline & VI. Neutral & ţogé & $k \tilde{\varepsilon}$ & $k \grave{\varepsilon}$ & nùké & gùké & káká & dùké \\
\hline \multirow[t]{3}{*}{ Negative } & VI. Basic negative & $m 6$ & h6 & hò & nùh 6 & gùh6 & káhó & dùh 6 \\
\hline & VII. Prohibitive & máháá & háá & $h \grave{a ̀ a ̀ ~}$ & nùháá & gùháá & káháá & dùháa \\
\hline & VIII. Conditional & nàà & 6àà & $\grave{a ̀ a ̀}$ & nwàà & gwàà & $k \grave{a ̀ a ̀}$ & dìà \\
\hline
\end{tabular}

81 The main affirmative and negative TAM constructions with predicative person markers are described in section 6 .

\subsection{Possessive person markers}

Possessive person markers are used in alienable possessive construction. They function as deictic/anaphoric markers and co-occur with full noun phrases in the possessor position (cf. 5.1).

Table 9. Possessive person markers.

\begin{tabular}{|c|c|c|c|c|c|c|}
\hline $1 \mathrm{sg}$ & $2 \mathrm{sg}$ & $3 s g$ & 1pl.excl & 1pl.incl & $2 \mathrm{pl}$ & $3 \mathrm{pl}$ \\
\hline$n^{\prime}$ & wó & $\eta \grave{\jmath}, \grave{y}$ & nùá & gùá & káá & dùá \\
\hline
\end{tabular}

\subsection{Locative person markers}

Locative person markers are fused with the locative postposition $m a$ 'on'. They function as deictic/anaphoric markers $(30,32)$ and co-occur with lexical complements, with some restrictions $(29,31)$. 
Similarly to basic negative markers discussed in 4.3 , locative person markers do not co-occur with singular full noun complements, except for noun phrases with definite markers (5.4), noun phrases encoded by person index with quantifier héné 'all' (5.5) and conjoint noun phrases (5.6). A "default" uninflected form of the postposition is used following singular complements (29). Locative markers are optionally used with plural nouns as complements (31).

\begin{tabular}{|l|l|l|l|l|l|l|}
\hline (29) & Pépèe & wóó & ká & HÉní & ma. & \\
\hline & Pepee & love & be & Heni & on & \\
\hline
\end{tabular}

\section{'Hعni loves Pepee’.}

\begin{tabular}{|l|l|l|l|l|l|}
\hline (30) & Pépèe & wóó & ká & mà. & \\
\hline & Pepee & love & be & 3sG.on & \\
\hline
\end{tabular}

'(S)he loves Pepee'.

\begin{tabular}{|l|l|l|l|l|l|l|}
\hline (31) & Pépèe & wóó & ká & léćplẹ̀à-yàa & mà / dùmá. & \\
\hline & Pepee & love & be & child.PL-PL & on / 3PL.on \\
\hline
\end{tabular}

'Children love Pepee'.

\begin{tabular}{|l|l|l|l|l|l|}
\hline (32) & Pépèe & wóó & ká & dùmá. \\
\hline & Pepee & love & be & 3PL.on \\
\hline
\end{tabular}

'They love Pepee'.

As with basic negative predicative and neutral person markers, the difference between the 3sG locative marker and the uninflected "default" marker is that the former always has low tone as in (33), while the tone of the latter is spread from the complement (cf. 34-35). Thus, $m a$ is lexically toneless in Kono (cf. bà in Guinean Kpelle, mà in Liberian Kpelle).

\begin{tabular}{|l|l|l|l|l|}
\hline (33) & Baa & lẹ̌̆ă & lóhòrò-kí & {$[$ mà]. } \\
\hline & 2SG.RES & forget & child-DEF & 3SG.on \\
\hline
\end{tabular}

'You forgot the child'. 


\begin{tabular}{|l|l|l|l|l|}
\hline$(34)$ & Baa & lèča & Pépèe & {$[$ mà].} \\
\hline & 2SG.RES & forget & Pepee & on \\
\hline
\end{tabular}

'You forgot Pepee'.

\begin{tabular}{|c|c|c|c|c|}
\hline (35) & $B a a$ & 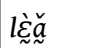 & Héní & [má]. \\
\hline & 2SG.RES & forget & HEni & on \\
\hline
\end{tabular}

'You forgot Heni'.

A full paradigm of locative person markers is given in Table 10.

Table 10. Locative person markers.

\begin{tabular}{|l|l|l|l|l|l|l|}
\hline 1SG & 2SG & $3 \mathrm{SG}$ & 1PL.EXCL & 1PL.INCL & 2PL & $3 \mathrm{PL}$ \\
\hline má & 6'îe & mà & nùmá & gùmá & kámá & dùmá \\
\hline
\end{tabular}

\subsection{Conjunctive person markers}

Conjunctive person markers are used for noun phrase conjunction (see 5.6).

Table 11. Conjunctive person markers.

\begin{tabular}{|c|c|c|c|c|}
\hline $1 \mathrm{SG}+3$ & $1 \mathrm{PL}+3$ & $1+2$ & $2+3$ & $3+3$ \\
\hline nà & $n w \grave{a}$ & 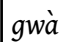 & kà & $d \grave{a}$ \\
\hline
\end{tabular}

\section{Noun phrase}

The order of nominal modifiers in the noun phrase is as follows:

(36) Possessor NP - possessed NP - attributive modifier - numeral/plural marker demonstrative - definiteness marker

\subsection{Possessive constructions}

97 As in many other Mande languages, nouns are classified into two major groups in Kono: free and relational; the latter group comprises kinship terms and body part names. The difference between free and relational nouns is two-fold. First, relational nouns are almost always used with a possessor. Second, relational and free nouns are used with 
different series of person markers encoding possessor, so-called person indexes (4.2) and possessive markers (4.4) respectively.

Inalienable possession markers used with relational nouns are person indexes that also encode verb and postposition complements, as well as single arguments in stativeresultative construction (6.17). 1SG and $3 \mathrm{SG}$ meanings are encoded by consonant alternation with high and low prefixal tones, respectively (cf. 2.4, 3.6).

Within relational nouns, there is a syntactic distinction between kinship terms and body part names in possessive constructions: person markers co-occur with possessors of kinship terms, but not of body part names. This yields three types of possessive constructions in Kono, given below for the nouns bláá 'sheep', leè 'mother' and kóyó 'leg'.

Table 12. Possessive constructions.

\begin{tabular}{|c|c|c|}
\hline & Anaphoric possessor & Lexical possessor \\
\hline Alienable (with free nouns) & $\begin{array}{l}\text { yò bláá 'his/her sheep' } \\
\text { dùá bláá 'their sheep' }\end{array}$ & 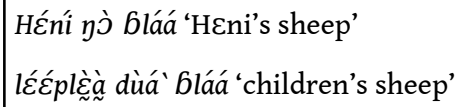 \\
\hline Inalienable (with kinship terms) & $\begin{array}{l}\text { ñèe 'his/her mother' } \\
\text { dülěe 'their mother' }\end{array}$ & 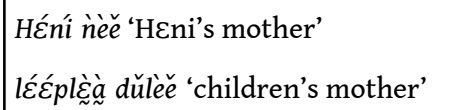 \\
\hline Inalienable (with body part names) & $\begin{array}{l}\text { gว̀yว̌ ‘his/her leg' } \\
\text { dǔkóxó 'their legs' }\end{array}$ & 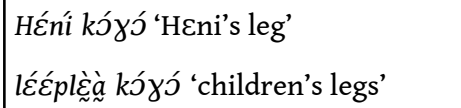 \\
\hline
\end{tabular}

In non-anchoring possessive constructions, the head noun is marked with /L/ melody:

\begin{tabular}{|c|c|c|}
\hline (37) & mààn & kગ̀j̀ \\
\hline & rice & bone $\backslash \mathrm{L}$ \\
\hline
\end{tabular}

101 'rice grain'

\subsection{Plural marking}

There are two plural markers in Kono: -ni for kinship terms and usually - $y a a^{10}$ for other nouns (however, cf. (41) with -ni marking yว̀ว 'bird').

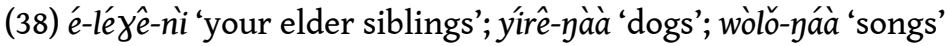

Some human nouns have irregular plural forms; these are given in Table 13.

Table 13. Irregular plural forms.

\begin{tabular}{|l|l|l|}
\hline Singular form & Plural form & Meaning \\
\hline nú / ní & núáà & ‘person' \\
\hline
\end{tabular}




\begin{tabular}{|c|c|c|}
\hline hìnènû & hìnàa & 'man' \\
\hline$n \varepsilon \grave{\varepsilon} n \hat{u}$ & 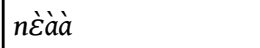 & 'woman' \\
\hline lókòrò & léćplè̃à & 'child' \\
\hline námû & námlàà & 'chief' \\
\hline dzòómún & dzówáà dzòyóbláà & 'organizer of male initiation' \\
\hline máráń & máráà máránàà & 'friend' \\
\hline
\end{tabular}

Irregular plural forms may be reinforced by a regular plural marker: léćplęàa-naa 'children'.

\subsection{Demonstratives}

106 yà 'this', yàméy 'that'

\subsection{Definiteness marker}

Definiteness is marked by the definite article - $k \dot{i}$ or sometimes - $\gamma^{\prime} i$ after vowels and $-\hat{i}$ after word final $-\eta$ :

(39) yá 'river' - yá-kí 'the river'; máráń ‘a friend of mine’ - márán-í 'my friend' (selected among friends of other people).

109 NPs with a -kí marker are always followed by resumptive pronominals, regardless of their syntactic position, i.e., direct objects, possessors of body part names, postposition complements and single arguments in stative-resultative construction (6.17; cf. section 4 on the distribution of person markers in Kono). This is illustrated for direct object position in (40-42):

\begin{tabular}{|l|l|l|l|}
\hline$(40)$ & Bò & y’̀ว̌-kí & $g b \grave{\varepsilon} !$ \\
\hline & 2SG.IMP & bird-DEF & 3SG \hunt \\
\hline
\end{tabular}

110 'Hunt the bird!'

\begin{tabular}{|l|l|l|l|}
\hline$(41)$ & Bò & ỳ̀ว̌-ni-kí & dǔ-kpć! \\
\hline & 2SG.IMP & bird-PL-DEF & 3PL-hunt \\
\hline
\end{tabular}

111 'Hunt the birds!'

\begin{tabular}{|c|c|c|c|c|}
\hline (42) & Bò & yว่ว้ & $k p \varepsilon^{\prime}$ & /*gb̀̀! \\
\hline
\end{tabular}




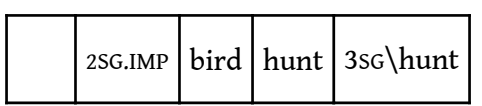

'Hunt a bird!'

113 In (40-41), a definite noun phrase in direct object position is doubled by 3SG (40) and 3PL (41) person prefixes. This is not possible for indefinite noun phrases as shown in (42).

114 Obligatory doubling of definite noun phrases is a very interesting syntactic property of Kono, which is not attested in other Kpelle varieties. However, it occurs in neighbouring Southern Mande languages, e.g., Dan-GweEtaa (Vydrine \& Kességbeu 2008:70-71).

\subsection{Quantifying expressions}

115 I have collected the following quantifying words, represented here with their surface tones: hénÉ 'all', tònò 'one', hwèrè 'two', hàbà 'three', náán 'four', lóólú 'five', mèydà 'six', mèhèrà 'seven', mèhàbà 'eight', mènáán 'nine', pòu 'ten'.

116 When there is quantifier hénć 'all', person indexes, but not lexical noun phrases, are doubled by resumptive pronominals, regardless of their syntactic position, e.g., direct objects (43-44):

\begin{tabular}{|c|c|c|c|c|}
\hline (43) & ń & dï-hénź & $d \grave{i}-k \grave{a}$ & Lòràà. \\
\hline & $1 \mathrm{SG} . \mathrm{B}$ & 3PL-all & 3PL-see $\backslash \mathrm{L}$ & Lola \\
\hline
\end{tabular}

117 'I saw them all in Lola'.

\begin{tabular}{|c|c|c|c|c|c|}
\hline (44) & $n ́$ & ḿáráa & héné & 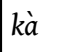 & Lòràà. \\
\hline & $1 \mathrm{SG} . \mathrm{B}$ & $1 \mathrm{SG} \backslash$ friend.PL & all & see $\backslash \mathrm{I}$ & Lola \\
\hline
\end{tabular}

118 'I saw all my friends in Lola'.

\subsection{Noun phrase conjunction}

119 Noun phrase conjunction is encoded by conjunctive person markers (cf. section 4.6 for the full paradigm).

120 Noun phrases are conjoined with an inclusory strategy (Haspelmath 2007:33) following a $1>2>3$ person hierarchy. The conjoint participant higher in the hierarchy is encoded by a conjunctive person marker, while the participant lower in the hierarchy is expressed by a full noun phrase (45) or a strong pronoun (46) following the person marker.

\begin{tabular}{|l|l|l|l|l|l|}
\hline$(45)$ & Nà & HÉní & $n \grave{u}$ & $p a ̀$. & \\
\hline
\end{tabular}




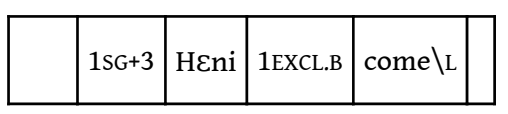

‘I and Heni came’.

\begin{tabular}{|l|l|l|l|l|}
\hline$(46)$ & $N a ̀$ & $y a ̀ ~$ & bó & pà. \\
\hline & $1 \mathrm{SG}+3$ & $3 \mathrm{SG} . \mathrm{AUT}$ & FOC & $\operatorname{come} \backslash \mathrm{L}$ \\
\hline
\end{tabular}

'I and he came'.

First person exclusive markers distinguish between two and more than two participants, cf. (45) and (47).

\begin{tabular}{|l|l|l|l|l|}
\hline$(47)$ & Nwà & Héní & $n \check{u}$ & pà. \\
\hline & $1 \mathrm{PL}+3$ & HEni & $1 \mathrm{EXCL.B}$ & $\operatorname{come} \backslash \mathrm{L}$ \\
\hline
\end{tabular}

'we and Heni came', but *'I and Heni came'.

Other conjunctive person forms are ambiguous as to whether there are two or more participants:

\begin{tabular}{|l|l|l|l|l|l|}
\hline (48) & Dà & HÉní & dù & pà. & \\
\hline & $3+3$ & HEni & 3PL.B & come $\backslash \mathrm{L}$ \\
\hline
\end{tabular}

'He and Hعni came' (2) or 'They and Heni came' (>2)

Two full noun phrases are conjoined by dà (47).

\begin{tabular}{|l|l|l|l|l|l|}
\hline (49) & Yàràmó & dà & Héní & dù & pà. \\
\hline & Yaramo & $3+3$ & Heni & 3PL.B & come $\backslash \mathrm{L}$ \\
\hline
\end{tabular}

'Yaramo and Heni came'.

All examples discussed here may also have a comitative interpretation, whereby the second participant is interpreted as accompanying the first one, e.g., 'Yaramo and Heni came' or 'Yaramo came with Heni' (in 49).

Similarly to noun phrases with definite markers (5.4) and person indexes with the quantifier héné 'all' (5.5), conjoint noun phrases are always doubled by person markers, regardless of their syntactic position, e.g., direct objects:

\begin{tabular}{|l|l|l|l|l|}
\hline$(50)$ & yá & [dà & Héníi & dǔ-kà. \\
\hline
\end{tabular}




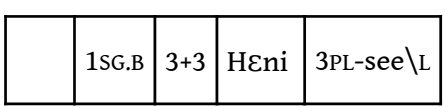

'I saw him/them and Heni'.

\section{Verb phrase}

The basic word order is (S) Aux O V X. Verb phrase consists of two essential elements in Kono: Aux, which may be realized as a predicative person marker (4.3) or as an uninflected predicative marker, e.g., after a lexical subject in negative constructions (57), and V, the verb. When there is no lexical subject, Aux is always realized as a predicative person marker. In what follows, I only provide special comments for those constructions that pattern differently with and without a lexical subject, (cf. 4.3), but they are by default the same. In transitive constructions, there is also a direct object before the verb. A third argument in ditransitive construction is encoded by a postpositional phrase following the verb. ${ }^{11}$

In various TAM constructions, the verb can have eitherlexical tone or low melody marked as /L/, which completely replaces lexical tone. In other constructions, the verb appears with lexical tone and a suffix. In this section, the basic Kono TAM constructions are described; each affirmative construction type is followed by its negative counterpart.

\subsection{Affirmative stative}

Affirmative stative: basic affirmative person markers + verb with lexical tone

\begin{tabular}{|c|c|c|c|}
\hline (51) & Máráyàà & $d \check{u}$ & é-klóńy. \\
\hline & 1SG \friend.PL & 3PL.B & 2sG-know \\
\hline
\end{tabular}

'My friends know you'.

\subsection{Negative stative}

Negative stative: basic negative person markers + verb with lexical tone (default negative marker ho after lexical subject)

\begin{tabular}{|l|l|l|l|l|}
\hline (52) & Mó & Yàràmó & klóý. & \\
\hline & 1SG.B.NEG & Yaramo & know & \\
\hline
\end{tabular}

137 'I don't know Yaramo’. 


\subsection{Affirmative past}

Affirmative past: basic affirmative person markers + verb with /L/

\begin{tabular}{|l|l|l|l|}
\hline (53) & Ḿáráyàà & $d \grave{u}$ & é-klò̀̀. \\
\hline & 1SG $\backslash$ friend.PL & 3PL.B & 2SG-know $\backslash \mathrm{L}$ \\
\hline
\end{tabular}

'My friends used to know you'.

\subsection{Negative past}

140 Negative past: basic negative person markers + verb with /L/ (default negative marker ho after lexical subject)

\begin{tabular}{|c|c|c|c|}
\hline (54) & Mó & Yàràmó & klòǹ. \\
\hline & 1SG.B.NEG & Yaramo & know $\backslash \mathrm{L}$ \\
\hline
\end{tabular}

141 'I didn't know Yaramo'.

\subsection{Affirmative habitual}

1) Basic affirmative person markers + verb with -à suffix.

\begin{tabular}{|l|l|l|l|l|l|}
\hline (55) & Lóhòrò-kí & $\grave{e}$ & tǒ-à & yèrè & hénć. \\
\hline & child-DEF & $35 G . B$ & fall-HAB & day & all \\
\hline
\end{tabular}

'The child falls all the time'.

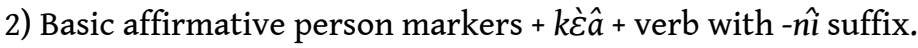

\begin{tabular}{|l|l|l|l|l|l|}
\hline (56) & Héní & $\grave{e}$ & $k \dot{\varepsilon} \hat{a}$ & $p a ́-n \hat{i}$ & $6 \grave{.}$ \\
\hline & HEni & $3 \mathrm{SG}$ & HAB & come-STAT & here \\
\hline
\end{tabular}

'Hعni often comes here'.

\subsection{Negative habitual}

146 1) Basic negative person markers + verb with -à suffix (default negative marker ho after lexical subject). 


\begin{tabular}{|l|l|l|l|}
\hline (57) & Héní & ho & tǒ-à. \\
\hline & Heni & NEG & fall-HAB \\
\hline
\end{tabular}

\begin{tabular}{|l|l|l|l|l|l|}
\hline (61) & É-lé $\hat{e}$-ni & daa & pá, & dùkáa & kóli. \\
\hline & 2SG-younger.sibling-PL & 3PL.RES & come & 3PL.EXI & yard.Loc \\
\hline
\end{tabular}

\begin{tabular}{|c|c|c|c|c|c|c|c|}
\hline (58) & HÉní & ho & $k \dot{\varepsilon} \hat{a}$ & bá & $m \varepsilon \check{\varepsilon}-n \hat{\imath}$ & yèrě & hÉné. \\
\hline & Heni & NEG & $\mathrm{HAB}$ & rice & eat-STAT & day & all \\
\hline
\end{tabular}

\section{'Hعni doesn't eat rice every day'.} adverbial modifier yèrě hÉnć 'every day'. following examples:

\begin{tabular}{|l|l|l|l|}
\hline (59) & Ĺx́́plè̃à & dùhó & tǒ-à. \\
\hline & child.PL & 3PL.B.NEG & fall-HAB \\
\hline
\end{tabular}

'Children don't fall'.

\begin{tabular}{|l|l|l|l|l|}
\hline$(60)$ & Léćplè̃å & dùhó & $k \dot{\varepsilon} \hat{a}$ & tǒ-nî. \\
\hline & child.PL & 3PL.B.NEG & HAB & fall-STAT \\
\hline
\end{tabular}

'Children don't often fall'. occurs sometimes.

\subsection{Affirmative resultative}

The semantic differences between the two pairs of affirmative and symmetric negative constructions require further clarification. Both constructions can be used with the

However, my consultant Bala Bamba indicated that in the first construction, the situation tends to be interpreted as generic, while the second construction refers to a sequence of regular concrete situations. This interpretation can be corroborated by the

Thus (59) means that the situation doesn't take place at all, while (60) means that it

Affirmative resultative: resultative person markers + verb with lexical tone. 
'Your younger siblings have come, they are in the yard'.

\subsection{Negative resultative}

157 Negative resultative: basic negative person markers + verb with-nî suffix (default negative marker ho after lexical subject).

\begin{tabular}{|l|l|l|l|}
\hline$(62)$ & Mó & nii & $p a ́-n \hat{i}$. \\
\hline & 1SG.B.NEG & yet & come-STAT \\
\hline
\end{tabular}

158 'I have not come yet'.

\subsection{Affirmative progressive}

159 Affirmative progressive: existential person markers + verb with -nî suffix (default marker ká after lexical subject (cf. 27, 69).

\begin{tabular}{|l|l|l|l|l|}
\hline (63) & Ńnà & wòlò & tò-nî. & \\
\hline & 1SG.EXI & song & throw-STAT & \\
\hline
\end{tabular}

'I am singing a song'.

\subsection{Negative progressive}

161 Negative progressive: basic negative person markers + nà + verb with -nî suffix (default negative marker ho after lexical subject).

\begin{tabular}{|c|c|c|c|c|}
\hline (64) & Mó & nà & wòlǒ & tò-nî. \\
\hline & 1SG.B.NEG & be & song & throw-STAT \\
\hline
\end{tabular}

162 'I am not singing a song'.

\subsection{Affirmative future}

Affirmative future: future person markers + pá + verb with lexical tone.

\begin{tabular}{|l|l|l|l|l|l|l|}
\hline (65) & Héní & wèć & $p a ́$ & $k l \hat{o}$ & $k$ ć & tináá. \\
\hline & Heni & 3sG.FuT & come & work & do & tomorrow \\
\hline
\end{tabular}


‘Hعni will work tomorrow'.

165 As in many other languages, the verb pá 'come' is grammaticalized into a future marker, though it is still also used as a lexical item.

\subsection{Negative future}

166 Negative future: basic negative person markers $+k \varepsilon \varepsilon+p a ́$ + verb with lexical tone (default negative marker ho after lexical subject).

\begin{tabular}{|l|l|l|l|l|l|l|}
\hline (66) & Mó & $k \varepsilon \varepsilon$ & pá & wááyj̀̀̀ & $t \grave{\varepsilon} \gamma \check{\text { É }}$ & é-pó. \\
\hline & 1SG.B.NEG & FUT & come & money & give & 2SG-to \\
\hline
\end{tabular}

167 'I will not give you money'.

\subsection{Imperative}

Imperative: imperative person markers + verb with lexical tone.

\begin{tabular}{|l|l|l|}
\hline$(67)$ & Kà & $p a ́ !$ \\
\hline & 2PL.IMP & come \\
\hline
\end{tabular}

169 'You (pl.) come!'

170 Note that there may be no person marker in 2SG: (Bò) pá! 'Come!'

\subsection{Prohibitive}

171 Prohibitive: prohibitive person markers + verb with /L/.

\begin{tabular}{|l|l|l|}
\hline$(68)$ & Hàa & pà. \\
\hline & 3SG.PROH & come $\backslash \mathrm{L}$ \\
\hline
\end{tabular}

'Let him not come'.

\subsection{Neutral}

173 Neutral: neutral person markers + verb with /L/ (default marker ké after lexical subject).

\begin{tabular}{|l|l|l|l|l|l|l|l|l}
\hline (69) & Héní & ká & hiè-nî, & Yàràmó & $k \varepsilon$ & wòlò & tò. \\
\hline
\end{tabular}




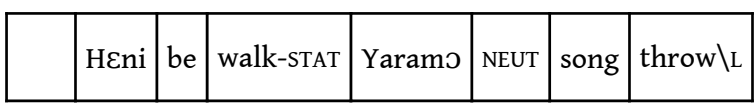

'Hعni is beautiful'.

'Heni is walking, and Yaramo is singing a song'.

When there is a full noun phrase in the subject position, a predicative marker appears in its default, lexically toneless form. Its surface tone is spread from the subject. When there is no lexical subject, the $3 \mathrm{SG}$ anaphoric marker $k \dot{\varepsilon}$ with low tone is used (cf. basic negative person markers (4.3) with similar distribution).

This construction is used in non-initial predication to encode simultaneous actions for processes and subsequent situations for single events ${ }^{12}$.

\subsection{Conditional}

Conditional: conditional person markers + verb with /L/.

\begin{tabular}{|c|c|c|c|c|c|c|c|}
\hline (70) & $N \hat{i} \hat{e}-n i$ & dàa & pà, & 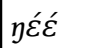 & Gláá & $t \grave{\varepsilon} \gamma \grave{\varepsilon}$ & ď̌-pó. \\
\hline & elder.sibling-PL & 3PL.COND & come $\backslash \mathrm{L}$ & 1SG.FUT & sheep & give $\backslash_{\mathrm{L}}$ & 3PL-to \\
\hline
\end{tabular}

'If my elder siblings come, I will give them a sheep'.

Unfortunately, I have not checked negative conditional construction.

\subsection{Stative-resultative}

Stative-resultative: person index + verb with vocALIC suffix + 6 ó.

This construction has non-nominative argument alignment and is characteristic of South-Western Mande languages. There is no predicative marker after the lexical subject and the anaphoric subject is encoded by person indexes, which are otherwise used in various non-subject positions including direct objects (4.2).

The verb appears with a vocalic suffix and a predicative particle bó. The form of vocalic suffix depends on the final vowel of the verb; however, my data are not sufficient for providing a complete description here. I have only checked qualitative verbs that receive a stative interpretation in this construction. In other Kpelle varieties, dynamic verbs are also used in this construction with a resultative interpretation. For this reason, I tentatively also labelled it "stative-resultative" in Kono.

\begin{tabular}{|l|l|l|l|}
\hline (71) & Héní & léré-é & 6ó. \\
\hline & Heni & be.beautiful-STAT & PRED \\
\hline
\end{tabular}

Note that verbs with a vocalic suffix can also be used attributively: 


\begin{tabular}{|c|c|c|}
\hline (72) & $n \dot{\varepsilon} \dot{\varepsilon} n \hat{u}$ & 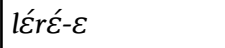 \\
\hline & woman & be.beautiful-STAT \\
\hline
\end{tabular}

\begin{tabular}{|c|c|c|c|c|c|}
\hline (75) & $N i \hat{i}$-ni & dùhó & nà & $\grave{a}$ & dǔ-léré-ć. \\
\hline & elder.sibling-PL & 3PL.NEG & be & PREP & 3PL-be.beautiful-STAT \\
\hline
\end{tabular}

Table 14. Basic TAM constructions

\begin{tabular}{|c|c|}
\hline Affirmative stative & Basic affirmative person markers + verb with lexical tone \\
\hline Negative stative & Basic negative person markers + verb with lexical tone \\
\hline Affirmative past & Basic affirmative person markers + verb with /L/ \\
\hline Negative past & Basic negative person markers + verb with /L/ \\
\hline Affirmative habitual & $\begin{array}{l}\text { 1) Basic affirmative person markers + verb with -à suffix } \\
\text { 2) Basic affirmative person markers + kغे } \hat{a}+\text { verb with -nî suffix }\end{array}$ \\
\hline
\end{tabular}




\begin{tabular}{|c|c|}
\hline Negative habitual & $\begin{array}{l}\text { 1) Basic negative person markers + verb with }-\grave{a} \text { suffix } \\
\text { 2) Basic negative person markers }+k \grave{\varepsilon} \hat{a}+\text { verb with }-\hat{n} \grave{i} \text { suffix }\end{array}$ \\
\hline Affirmative resultative & Resultative person markers + verb with lexical tone \\
\hline Negative resultative & Basic negative person markers + verb with-nî suffix \\
\hline Affirmative progressive & Existential person markers + verb with -nî suffix \\
\hline Negative progressive & Basic negative person markers + nà + verb with $-n \hat{\imath}$ suffix \\
\hline Affirmative future & Future person markers $+p a ́$ + verb with lexical tone \\
\hline Negative future & Basic negative person markers $+k \varepsilon \varepsilon+p a ́+$ verb with lexical tone \\
\hline Imperative & Imperative person markers + verb with lexical tone \\
\hline Prohibitive & Prohibitive person markers + verb with /L/ \\
\hline Neutral & Neutral person markers + verb with /L/ \\
\hline Conditional & Conditional person markers + verb with /L/ \\
\hline $\begin{array}{l}\text { Affirmative } \\
\text { stative-resultative }\end{array}$ & Person index + verb with vocalic suffix + bó \\
\hline Negative stative-resultative & $\begin{array}{l}\text { Basic negative person markers }+ \text { nà copula }+\grave{a}+\text { person index }+ \text { verb } \\
\text { with vocalic suffix }\end{array}$ \\
\hline
\end{tabular}

\subsection{Comparison of TAM systems in three Kpelle varieties}

As shown in 6.9, a special existential person series is used in progressive construction in Kono. This series has an extraordinarily mixed paradigm, incorporating person markers fused with two different predicators, nà and ká; cf. series III in Table 8.

In Liberian Kpelle there are two progressive constructions. In the first, a special nonpast series of person markers is used, which also occurs in the future and habitual construction (76). In the second one, a non-nominative subject is used with káa existential predicator, cognate to ká in Kono (77). In both constructions, the verb appears in the infinitive form with $-i$ suffix.

\begin{tabular}{|l|l|l|}
\hline$(76)$ & $\eta \bar{a}$ & $p a ́-i$. \\
\hline & 1 SG.NONPST & come-INF \\
\hline
\end{tabular}

'I am coming'. 


\begin{tabular}{|l|l|l|}
\hline (77) & ந́gáá & $p a ́-i$. \\
\hline & $1 \mathrm{sG} \backslash$ be & come-INF \\
\hline
\end{tabular}

\begin{tabular}{|l|l|l|l|}
\hline$(80)$ & $\eta_{\bar{a}}$ & $p a ́-i$ & $p a ́-i$. \\
\hline & 1 1sG.NONPST & come-INF & come-INF \\
\hline
\end{tabular}

\begin{tabular}{|l|l|l|l|l|}
\hline$(81)$ & Igáá & $p a ́-i$ & $d \bar{a}$ & $k$ óríi-i. \\
\hline & $1 \mathrm{sG} \backslash$ be & come-INF & $3 \mathrm{SG} \backslash$ some & look_for-INF \\
\hline
\end{tabular}




\begin{tabular}{|l|l|l|l|l|}
\hline$(82)$ & Gáá & pá-i & Pépèe & tólú-i. \\
\hline & $1 \mathrm{sG} \backslash \mathrm{be}$ & come-INF & Pepee & call-INF \\
\hline
\end{tabular}

\section{Swadesh lists for Kono, Guinean Kpelle and Liberian Kpelle} When the lexemes are etymologically identical in the three idioms, they are given in plain type. Lexemes that are identical in Guinean Kpelle and Kono, but are distinct from those in Liberian Kpelle, are given in italic. Lexemes that are identical in Liberian Kpelle and Kono, as opposed to those in Guinean Kpelle, are given in bold. When a Kono lexeme is different from a lexeme common for Guinea and Liberian Kpelle, it is underlined. When the three varieties have three distinct forms, they are given in bold italic. 
Table 15. Collection of 100-word Swadesh lists for the three Kpelle varieties

221 When analysing the data, I largely followed recommendations in Kassian et al. (2010), also discussed in Vydrin (2013). The results of pairwise cognate comparisons of the Kpelle varieties are given in Table 16.

Table 16. Pairwise cognate comparisons.

\begin{tabular}{|l|l|l|}
\hline & Kono & Liberian Kpelle \\
\hline Guinean Kpelle & 90 & 94 \\
\hline Kono & & 89 \\
\hline
\end{tabular}

222 As shown in Table 16, Kono is the most divergent variety, sharing $90 \%$ of cognates with Guinean Kpelle and 89\% with Liberian Kpelle. Such discrepancy parallels some specific grammatical properties attested in Kono, which are discussed in sections 5 and 6 . Hence, though it is not the goal of this sketch to suggest an appropriate taxonomic label, Kono may be considered a separate language, at least on linguistic grounds.

\section{Abbreviations}

AUT - free pronoun

B - basic person markers

COND - conditional person marker

DEF - definite 


\section{BIBLIOGRAPHY}

Bearth, Thomas. 1992. La pertinence latente. A propos du traitement des liquides et de la nasalisation dans les langues dites « sans consonnes nasales ». Verbum 15: 4, pp. 203-218.

Casthelain Jules. 1952. La langue guerzé: Grammaire et dictionnaire. (Mémoires de l'Institut français d'Afrique noire, 20). Dakar : I.F.A.N.

Haspelmath, Martin. 2007. Coordination. In: Shopen, Timothy (ed.). Language typology and syntactic description, vol. II: Complex constructions. 2nd ed. Cambridge: Cambridge University Press, pp. 1-51.

Kassian Alexei, Starostin George, Dybo Anna \& Chernov Vasily. 2010. The Swadesh wordlist. An attempt at semantic specification. Journal of Language Relationship 4, pp. 46-89.

Konoshenko Maria. 2008. Tonal systems in three dialects of the Kpelle language. Mandenkan 44, pp. 21-42.

Konoshenko Maria. 2010. Indirect object marking in Kpelle: Dative pronominals and postpositional agreement. In: Konstantin Pozdniakov, Valentin Vydrin, Alexander Zheltov (eds.). Personal pronouns in Niger-Congo languages: International workshop. St. Petersburg, September 13-15, 2010. Abstracts and papers: Working materials. St. Petersburg, pp. 52-56. 
Konoshenko Maria. 2014. The syntax of tone in Guinean Kpelle. Proceedings of the fortieth annual meeting of the Berkeley Linguistics Society. February 7-9. Berkeley.

Lassort P. 1952. Grammaire guerzé. (Mémoires de l'Institut français d'Afrique noire, 20.) Dakar : I.F.A.N.

Leidenfrost T.E. \& McKay J.S. 2007. Kpelle-English dictionary with a grammar sketch and English-Kpelle finderlist. Moscow (USA) : Palaverhut Press.

Leger J. 1975. Dictionnaire guerze. Nzérékoré.

Le Saout, J. 1979. Notes sur la phonologie du Gouro (zone de Zuénoula). Nice : C.E.P.L.A.N.

Makeeva, Nadezda. 2012. Grammatičeskij stroj jazyka kla-dan $v$ tipologičeskom kontekste rodstvennyx jazykov [A grammar of Kla-Dan and the typology of Mande languages]. PhD thesis. Institute of linguistics, Moscow.

Vydrine Valentin. 2014. Goo, neizvestnyj jazyk mande [Goo, an unknown Mande language]. In: A. Zheltov (ed.). Antropologija i lingvistika. Materialy peterburgskix ekspeditsij v Afriku. SPb: MAE RAN. pp. 67-127.

Vydrine Valentin, Kességbeu Mognan A. 2008. Dictionnaire Dan - Français (dan de l'Est) avec une esquisse de grammaire du dan de l'Est et un index français-dan. St Pétersbourg: Nestor-Istoria.

Welmers William. 1969. The morphology of Kpelle nominal. Journal of African Languages 8: 2, pp. 73-101.

Welmers William. 1962. The phonology of Kpelle. Journal of African Languages 1:1, pp. 69-93.

Westermann Diedrich. 1921. Die Kpelle, ein Negerstamm in Liberia. Göttingen : Vandenhoeck und Ruprecht.

Westermann Diedrich. \& Melzian Hans J. 1930. The Kpelle language in Liberia. Grammatical outline, colloquial sentences and vocabulary. Berlin: Reimer.

\section{NOTES}

1. This paper is written with financial support from the Russian Humanitarian Science Foundation, project 14-04-00488 "Language contact in Africa".

2. In Liberian and Guinean Kpelle, these alternations also mark definiteness, but there is no such marker in Kono; cf. 5.4.

3. Alternants for obstruents are always the same for $1 \mathrm{sG}$ and $3 \mathrm{sG}$ prefixes in Guinean Kpelle and as

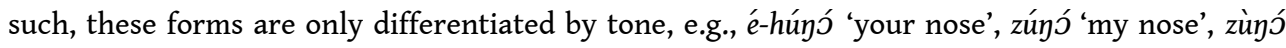
'his nose’; é-kóyó ‘your leg’, góyó ‘my leg’, gòyó ‘his leg’. However, in Liberian Kpelle, a nasal appears with an alternated consonant in 1SG form yielding a three-way contrast. The difference may be represented as $\mathrm{C}_{1}$ - for lexical consonant, $\mathrm{NC}_{2}$ - for $1 \mathrm{sg}, \mathrm{C}_{2}$ - with low tone for alternated

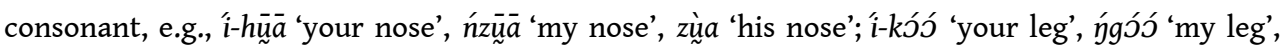
gòó 'his leg'.

4. Other nasals - /ym/, /nv/ and word initial/y/ - are never lexical; they only occur as a result of the alternation.

5. Surprisingly, $\operatorname{ClV}(\mathrm{y})$ stems behave differently as opposed to stems with no elision such as kérén 'burn': prefixal low tone is spread on its entire stem yielding /L(H)/ melody: [náá gèrèn'] 'I have burnt it', rather than the expected [*gèréń]. I have no explanation for this discrepancy at present. 
6. This process is not usually labelled "contour simplification", but I mention it here because it is functionally similar to the previous one, i.e., $\mathrm{L}$ absorption

7. Verbs in (14) and (15) get underlying /L/ in Affirmative Past construction - cf. 3.7, 6.3.

8. What seems to happen here is $\mathrm{L}$ plateauing between two floating $(\mathrm{H})$ tones, so the resulting tone is contextual $\mathrm{M}$. The same tonal change yielding a contextual mid tone is attested in tónónààlôi dialect of Guinean Kpelle described in (Konoshenko 2008). In hớગ kw later chose as representative of Guinean Kpelle and described in (Konoshenko 2014), /L(H)/ changes to /H/ in such environment.

9. The term "prefixal" is etymologically rather than synchronically adequate because there are no segmentable pre-stem markers in $1 \mathrm{SG}$ and $3 \mathrm{sG}$, but they can be reconstructed as $1 \mathrm{SG}^{*} \boldsymbol{\eta}^{\prime}$ - and

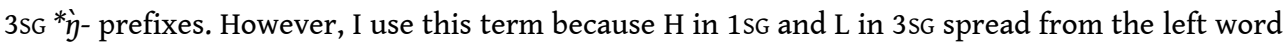
boundary and do not replace the stem tone completely, in contrast with the replacive /L/ pattern (cf. 3.7).

10. I am not sure about the underlying tones of these markers, which may have surface forms [nî] / [-nì] and [-yáà] / [-yàà]. More data are needed to discover how tonal rules work in these cases. Surface tones are represented in (38).

11. As demonstrated in Konoshenko (2014), postpositional phrases are clause adjuncts in Guinean Kpelle and are therefore outside verb phrases. I assume this to also be the case in Kono, though I have not applied relevant tests to check whether this is true.

12. This construction is labelled "neutral" in Kono by analogy with an identical construction in Guinean Kpelle. In Guinean Kpelle, the "neutral" construction is opposed to so-called "consecutive" construction. While the latter is only used to mark subsequent but not simultaneous events, the former can be used for both types of events; hence, it is labelled "neutral".

13. For the sake of uniformity, I have modified the orthography in Liberian Kpelle data taken from Leidenfrost \& McKey (2005).

\section{ABSTRACTS}

Kono (knu) is a Southwestern Mande lect of the Republic of Guinea, not to be confused with Kono of Sierra Leone (kno, Kono-Vai group). It is a member of the Kpelle macro-language together with Guinean Kpelle (gkp) and Liberian Kpelle (xpe). This paper is a brief description of Kono based on the author's field notes collected in the Republic of Guinea in 2009 and 2014. I discuss segmental and tonal phonology of Kono as well as its basic morphology and grammatical constructions. 100-word Swadesh lists for Kono, Guinean and Liberian Kpelle are also provided. As I demonstrate in this sketch, Kono is lexically and grammatically distinct enough to be considered a separate language. Some phonological and grammatical phenomena in Kono, e.g. consonant harmony, first vowel elision in CVLV structures and obligatory pronominal doubling of definite noun phrases, suggest that, unlike other Kpelle lects, Kono has undergone a strong contact influence from Southern Mande.

Kono (knu) est un parler mandé-sud-ouest de la République de Guinée, à ne pas confondre avec le kono de la Sierra Leone (kno, groupe Kono-Vai). Il est membre de la macro-langue kpelle conjointement avec le guerzé (kpelle de la Guinée, gkp) et le kpelle du Libéria (xpe). Cet article est une brève description de Kono sur la base des notes de terrain de l'auteur recueillies dans la 
République de Guinée en 2009 et 2014. Je décris la phonologie segmentale et tonale de kono ainsi que sa morphologie de base et des constructions grammaticales. Des listes Swadesh de 100 mots sont aussi données pour le kono, le guerzé et le kpelle du Libéria. Comme je le démontre dans cette esquisse, le kono est lexicalement et grammaticalement assez différent pour être considéré comme une langue indépendante. Certains phénomènes phonologiques et grammaticaux en kono, par exemple, l'harmonie consonantique, l'élision de la première voyelle dans les structures CVLV et le doublement pronominal obligatoire des syntagmes nominaux définis, suggèrent que, contrairement à d'autres parlers kpelle, le kono a subi une forte influence des langues mandésud.

НА ИДИОМЕ КОНО (knu) ГОВОРЯТ В РЕСПУБЛИКЕ ГВИНЕЯ, ОН ОТНОСИТСЯ К ЮГО-ЗАПАДНОЙ ГРУППЕ МАНДЕ, В ОТЛИЧИЕ ОТ КОНО (kno) ИЗ СЬЕРРА ЛЕОНЕ (ГРУППА КОНО-ВАИ). КОНО ВХОДИТ В МАКРОЯЗЫК КПЕЛЛЕ ВМЕСТЕ С ГВИНЕЙСКИМ КПЕЛЛЕ (gkp) И ЛИБЕРИЙСКИМ КПЕЛЛЕ (хре). СТАТЬЯ ПРЕДСТАВЛЯЕТ СОБОЙ КРАТКОЕ ОПИСАНИЕ ИДИОМА КОНО НА ОСНОВЕ ПОЛЕВЫХ МАТЕРИАЛОВ АВТОРА, СОБРАННЫХ В РЕСПУБЛИКЕ ГВИНЕЯ В 2009 И 2014 ГГ. В СТАТЬЕ ДАНЫ СВЕДЕНИЯ О СЕГМЕНТНОЙ ФОНОЛОГИИ И ТОНАЛЬНЫХ ПРАВИЛАХ, БА ЗОВОЙ МОРФОЛОГИИ, ОСНОВНЫХ ГРАММАТИЧЕСКИХ КОНСТРУКЦИЯХ КОНО. ТАКЖЕ ПРИВЕДЕНЫ СТОСЛОВНЫЕ СПИСКИ СВОДЕША ДЛЯ КОНО, ГВИНЕЙСКОГО И ЛИБЕРИЙСКОГО КПЕЛЛЕ. ПОКАЗАНО, ЧТО ЛЕКСИЧЕСКИ И ГРАММАТИЧЕСКИ КОНО ДОСТАТОЧНО СИЛЬНО ОТЛИЧАЕТСЯ ОТ ДРУГИХ ИДИОМОВ КПЕЛЛЕ И МОЖЕТ СЧИТАТЬСЯ ОТДЕЛЬНЫМ ЯЗЫКОМ. БОЛЕЕ ТОГО, НЕКОТОРЫЕ ФОНОЛОГИЧЕСКИЕ И ГРАММАТИЧЕСКИЕ ОСОБЕННОСТИ КОНО, НАПРИМЕР, КОНСОНАНТНАЯ ГАРМОНИЯ, ЭЛИЗИЯ ПЕРВОГО ГЛАСНОГО В СТРУКТУРАХ CVLV И ОБЯЗАТЕЛЬНОЕ МЕСТОИМЕННОЕ ДУБЛИРОВАНИЕ ОПРЕДЕЛЕННЫХ ИМЕННЫХ ГРУПП, ПОЗВОЛЯЮТ ПРЕДПОЛОЖИТЬ, ЧТО, В ОТЛИЧИЕ ОТ ДРУГИХ ИДИОМОВ КПЕЛЛЕ, КОНО ПОДВЕРГАЛСЯ ЗНАЧИТЕЛЬНОМУ КОНТАКТНОМУ ВЛИЯНИЮ СО СТОРОНЫ ЮЖНЫХ МАНДЕ.

\section{INDEX}

Mots-clés: langues mandé-sud-ouest, langues mandé-sud, alternance de consonnes, harmonie consonantique, règles tonales, constructions possessives, constructions TAM, liste Swadesh, salutations, contact linguistique

motsclesru ЮГО-ЗАПАДНЫЕ МАНДЕ, ЮЖНЫЕ МАНДЕ, ЧЕРЕДОВАНИЯ, ГАРМОНИЯ СОГЛАСНЫХ, ТОНАЛЬНЫЕ ПРАВИЛА, ПОСЕССИВНЫЕ КОНСТРУКЦИИ, ВИДО-ВРЕМЕННЫЕ КОНСТРУКЦИИ, СПИСКИ СВОДЕША, ПРИВЕТСТВИЯ, ЯЗЫКОВЫЕ КОНТАКТЫ

Keywords: Southwestern Mande, Southern Mande, consonant alternation, consonant harmony, tonal rules, possessive constructions, TAM constructions, Swadesh list, greetings, language contact

\section{AUTHOR}

\section{MARIA KONOSHENKO}

Russian State University for the Humanities, Moscow mb_konoshenko@il-rggu.ru 